\title{
Patterns of prey selection of Trypoxylon (Trypargilum) lactitarse Saussure (Hymenoptera: Crabronidae) in southern Brazil
}

\author{
Buschini, MLT. ${ }^{\mathrm{a} *}$, Borba, NA. ${ }^{\mathrm{a}}$ and Brescovit, AD. ${ }^{\mathrm{b} *}$ \\ aDepartamento de Biologia, Universidade Estadual do Centro Oeste - UNICENTRO, \\ Rua Presidente Zacarias, 875, Santa Cruz, CEP 85010-990, Guarapuava, PR, Brazil \\ 'baboratório de Artrópodes Peçonhentos, Instituto Butantan, \\ Av. Vital Brasil, 1500, CEP 05503-900, São Paulo, SP, Brazil \\ *e-mail: isatunes@yahoo.com.br, adbresc@terra.com.br
}

Received December 18, 2006 - Accepted May 25, 2007 - Distributed August 31, 2008

(With 6 figures)

\begin{abstract}
This study was carried out in the Parque Municipal das Araucárias, in the municipality of Guarapuava, southern Brazil. A total of 449 T. lactitarse nests were collected using trap-nests of different diameters. Fifty three species of spiders belonging to 7 families were captured by T. lactitarse. Araneidae was the most captured family and has been strongly represented by the genus Eustala. Through Bray-Curtis's coefficient and the unweighted pair group method average (UPGMA), the spiders species can be divided into 3 groups: the smaller group includes the most abundant species (Eustala sp1, Eustala sp2, Acacesia villalobosi, Alpaida sp1 and Araneus corporosus), the second group includes species with intermediate abundance (Wagneriana iguape, Araneus omnicolor, Eustala sp4, Alpaida grayi, Eustala sp3, Larinia t-notata, Mangora sp1 and Wagneriana iguape), and the third and largest group includes the least abundant species (Aysha gr. brevimana 1, Eustala sp5, Wagneriana eupalaestra, Alpaida scriba, Alpaida veniliae, Araneus aff. omnicolor, Araneus sicki, Eustala sp8, Mangora sp2, Mangora sp3, Wagneriana juquia, Alpaida sp2, Araneus blumenau, Eustala sp6, Eustala sp7 and Ocrepeira galianoae). Of 2,029 identified spiders, 1,171 were captured in the Araucaria forest, 612 in grassland areas and 246 in the swamp. Grassland and swamp areas evidenced greater similarity between them than to the Araucaria Forest, regarding presence-absence of spider species in T. lactitarse's diet, as well as regarding species abundance in these habitats. The juvenile number (56\%) was significantly higher than the female $(38 \%)$ and male $(6 \%)$ percentages.
\end{abstract}

Keywords: Crabronidae, spiders, Trypoxylon, prey selection.

\section{Padrões de seleção de presas por Trypoxylon (Trypargilum) lactitarse Saussure (Hymenoptera: Crabronidae) no sul do Brasil}

\section{Resumo}

Este estudo foi realizado no Parque Municipal das Araucárias, município de Gurarapuava, Sul do Brasil. Através de ninhos armadilhas de diferentes diâmetros, foram coletados 449 ninhos de Trypoxylon lactitarse. Cinqüenta e três espécies de aranhas pertencentes a 7 famílias foram capturadas por T. lactitarse. Araneidae foi a família mais freqüente, sendo fortemente representada pelo gênero Eustala. Através do índice de Bray-Curtis e do método de agrupamento (UPGMA), as espécies de aranhas foram divididas em três grupos: o primeiro e menor deles, formado pelas espécies abundantes (Eustala sp1, Eustala sp2, Acacesia villalobosi, Alpaida sp1 e Araneus corporosus); o segundo, pelas espécies intermediárias (Wagneriana iguape, Araneus omnicolor, Eustala sp4, Alpaida grayi, Eustala sp3, Larinia t-notata, Mangora sp1 e Wagneriana iguape); e o terceiro e maior deles, pelas espécies menos abundantes (Aysha gr. brevimana 1, Eustala sp5, Wagneriana eupalaestra, Alpaida scriba, Alpaida veniliae, Araneus aff. omnicolor, Araneus sicki, Eustala sp8, Mangora sp2, Mangora sp3, Wagneriana juquia, Alpaida sp2, Araneus blumenau, Eustala sp6, Eustala sp7 e Ocrepeira galianoae). Das 2.029 aranhas identificadas, 1.171 foram capturadas na mata de araucárias, 612 no campo e 246 na várzea. As áreas de campo e várzea foram as mais similares entre si, tanto com relação à presença e ausência, quanto com relação à abundância de espécies de aranhas na dieta de T. lactitarse. O número de jovens (56\%) foi significativamente maior que a de fêmeas (38\%) e de machos (6\%).

Palavras-chave: Crabronidae, aranhas, Trypoxylon, seleção de presas. 


\section{Introduction}

The wasp genus Trypoxylon, subgenus Trypargilum Richards occurs in temperate and tropical regions of the Western hemisphere (Bohart and Menke, 1976). The genus includes 359 species, distributed worldwide, of which 85 species belong to the subgenus Trypargilum (Coville, 1982). According to Richards (1934), Trypargilum is further subdivided into 5 groups: albitarse, superbum, punctulatum, spinosum and nitidium. This genus is poorly known in Central and South America, where higher species diversity is concentrated (Coville, 1982).

Like most crabronids, Trypargilum is solitary in the sense that each female constructs and provisions her own nest. The female begins the construction of the nest with a layer of mud, followed by the formation of a linear series of 6-8 cells, with mud partitions between them. Cells are provisioned with paralyzed spiders. Unlike most crabronids, however, males of Trypargilum usually guard the nest while it is being provisioned by the female, chasing away ants, parasitic flies and cuckoo wasps (Brockmann and Grafen, 1989). After laying a single large egg on the stored spiders, the female immediately builds a mud partition and begins to provision for the next brood cell in the nest. The egg hatches into a larva that consumes the provided food and then spins a cocoon (Brockmann and Grafen, 1992).

Several studies have been carried out in order to record and discuss the temporal patterns of prey selection shown by Trypoxylon species, since this information is important for both evolutionary and taxonomic perspectives (Genaro et al., 1989). Species and species groups of Trypargilum differ in the number and percentage of spider families they prey on, and the proportion of orb-weaving spiders, araneiod sheet web weavers, and even several spider taxa that usually do not use webs for capture (Krombein, 1967; Matthews and Matthews, 1968; Coville, 1982). This variation is also observed between individuals of the same species, because they hunt in different areas and become conditioned to certain types of spiders or certain types of hunting behavior (Coville, 1987).

Since Trypoxylon lactitarse is amply distributed in America, occurring from Canada to Argentina (Coville, 1982) and considering the fact that in Guarapuava (PR) it founds its nests in different habitats (Buschini and Wolff, 2006), the aim of this study was to investigate if the spider species captured by this wasp differ according to their habitat. Also, if the proportion of species collected in southern Brazil was different from that collected for T. lactitarse in other Brazilian regions (Camillo and Brescovit, 1999a).

\section{Material and Methods}

\subsection{Study areas}

This study was carried out in the Parque Municipal das Araucárias, in the municipality of Guarapuava, state of Paraná, southern Brazil (25 $23^{\prime} \mathrm{S}$ and $51^{\circ} 27^{\prime} \mathrm{W}$, $1,120 \mathrm{~m}$ of altitude). This area is characterized by a wet, cool season, and during the warmest months the average temperature is less than $22{ }^{\circ} \mathrm{C}$. Hoar frosts are common and severe.

Collections were carried out from December 2001 to December 2004 and were concentrated in a very heterogeneous site, with Araucaria forests, swamps and grasslands. The grasslands are characterised, physionomically, by areas of low grasses and no bushes. Species belonging to Ciperaceae, Leguminosae, Verbenaceae, Compositae and Umbeliferae are the main ones found in this habitat. Surrounded by the grasslands is the Araucaria forest, where there is a predominance of Araucaria angustifolia (Bertolini) O. Kuntze (Coniferae; Araucariaceae). The swamps are located in the lowest regions of the park composed mainly of grasses and Compositae.

\subsection{Sampling program}

Nests of T. lactitarse were obtained using trap-nests made out of $25 \times 20 \times 120 \mathrm{~mm}$ wooden boxes (Araucaria angustifolia), drilled longitudinally to a depth of $80 \mathrm{~mm}$ with 7.0, 10.0, and $13.0 \mathrm{~mm}$ aperture diameters. Before being drilled, the wooden blocks were sawed in half longitudinally and then held together with adhesive tape to allow the examination of the cavities when opened.

For each habitat, two areas were studied, with 2 transects per area and 4 sampling stations per transect. Twelve trap-nests were placed at each sampling station, four of each opening diameter, totaling 576 traps. Each trap was placed at $1.5 \mathrm{~m}$ above the ground and inspected every two weeks. In each inspection, all completed $T$. lactitarse nests were removed and immediately replaced with empty traps of the same diameter. The nests were then brought to the laboratory in order to investigate their contents. If eggs and/or larvae were present, the nest was closed to allow the completion of the lifecycle and the emergence of the adults. All spiders from cells with dead eggs or larvae were removed and identified. Abundance was calculated according to sex, development stage, family, genus and species.

\subsection{Statistical analyses}

Three indices were used to investigate the diversity of spider species in the diet of T. lactitarse in each of the habitats where they founded their nests: species richness (Margalef's index), Shannon-Wiener diversity and species evenness (Pielou's J index) (Ludwig and Reynolds, 1988). The statistic $t$-test was carried out in order to analyze the null hypothesis of no difference between the Shannon-Wiener values (Magurran, 2004).

To investigate the changes in species composition between habitat partitions, spiders were grouped according to abundance, using Bray-Curtis's coefficient, as a metric and the unweighted pair group method average (UPGMA) as the clustering method (Ludwig and Reynolds, 1988). The cophenetic coefficient of correlation was calculated in order to assess the appropriate- 
ness of the dendrograms. This same analysis was used to investigate the similarity between spider species abundances in T. lactitarse's diet. Jaccard's index was also used to measure the similarity between the habitats in relation to presence-absence of spider species collected by $T$. lactitarse. Similarity matrices were compared using the Mantel test (Mantel, 1967).

Spider species dominance was calculated according to Palma (1975): $\mathrm{D}=$ (Abundance of species $\mathrm{i} \div$ total abundance) $\times 100$. If $\mathrm{D}>5 \%$, the species is termed a dominant species; if $2.5 \%<\mathrm{D}<5 \%$, the species is termed an accessory species; if $\mathrm{D}<2.5 \%$, the species is termed an incidental species.

Chi-square tests were used to test the null hypothesis related to the proportion of collected juveniles, males and females.

\section{Results}

\subsection{Seasonality and nesting activity of} Trypoxylon lactitarse in different habitats

A total of $449 T$. lactitarse nests were collected. Nests were more frequently found in the Araucaria forest $(n=313)$ than in the grassland $(n=73)$ and swamp $(n=63)$ areas.

Nests were built more often during the summer (between December and March), during high temperature periods (Figure 1).

\subsection{Species of spiders collected and phenology of those most abundant}

Fifty three species of spiders belonging to 7 families were captured by $T$. lactitarse. Araneidae was the most captured family with 1,957 individuals $(96.5 \%)$, distributed among 11 genera (55\%) and 38 species (72\%).



Figure 1. Seasonal variation in the number of nests of T. lactitarse obtained monthly, from December, 2001 to December 2004.
Eustala $\mathrm{sp} 1$ was the most frequently captured species with 196 individuals. This species was captured throughout 7 months, most frequently during January, February and March. Eustala sp2, the second most frequent species, was also captured throughout 7 months, most frequently in December, January and February. The third most captured species was Alpaida sp1 with 116 individuals. This species was captured throughout 4 months, being most frequent in November, December and January (Figure 2). Approximately half of the individuals belonging to this family were juveniles and could not be identified beyond family level.

Anyphaenidae was the second most captured family, with 61 individuals (3\%), distributed in 2 genera (10\%) and 6 species (11\%). Aysha gr. brevimana sp1 was the most captured species with five individuals collected during the months of March and December. As was the case with Araneidae, 50 individuals (82\%) were juveniles and could not be identified beyond family level.

Tetragnathidae, represented by 7 individuals $(0,34 \%)$, belonging to 3 genera ( $15 \%$ ) and 5 species $(9,4 \%)$, was the third most frequently captured family. Chrysometa $\mathrm{sp} 2$, with two individuals captured in February and March, was the most frequently captured species. All other species were represented by a single individual.

Deinopidae and Oxyopidae, each with a single individual captured in January, Salticidae, with one individual captured in December and Uloboridae, with one individual captured in February, were also used by T. lactitarse to feed their young.

\subsection{Most abundant species of spiders in the} Araucaria forest, grassland and swamp areas

Of 2,029 identified spiders, 1,171 were captured in the Araucaria forest, 612 in grassland areas and 246 in

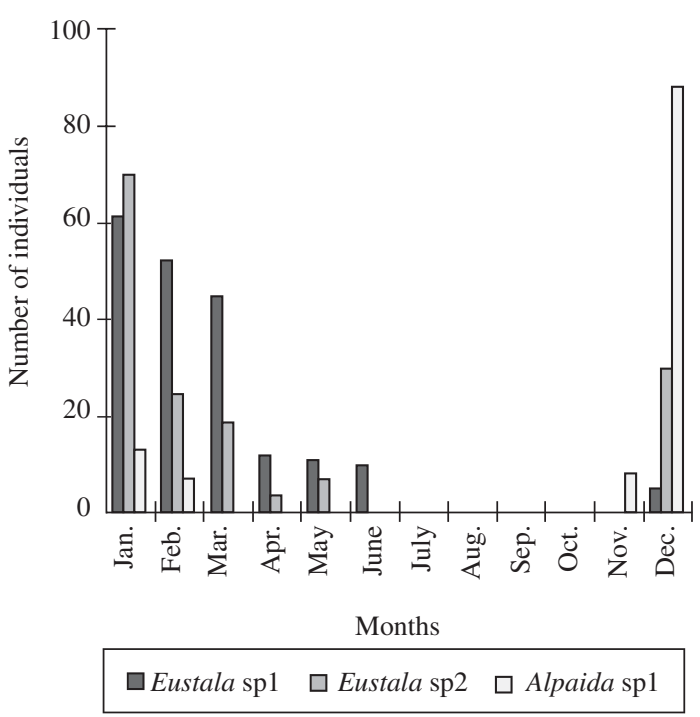

Figure 2. Monthly percent of prey species most frequently collected for T. lactitarse from December 2001 to December 2004. 
the swamp. Acacesia villalobosi, Araneus omnicolor, Araneus corporosus, Eustala $\mathrm{sp} 1$, Eustala sp2, Eustala sp7 e Mangora sp1 were common to all three habitats. Aysha gr. brevimana sp4, Aysha rubromaculata, Aysha sp3, Alpaida gracia, Alpaida veniliae, Araneus aurantiifemuris, Bertrana rufostriata, Eustala sp5, Eustala sp9, Mangora sp2, Mangora sp5, Wagneriana eupalaestra, Wagneriana janeiro, Wagneriana neglecta, Chrysometa boraceia, Chrysometa ludibunda, Chrysometa sp2, Leucauge sp. and Tetragnatha sp1 as well as the individuals of the families Deinopidae, Oxyopidae and Salticidae were found exclusively in the Araucaria Forest. Sanogasta sp3, Araneus omnicolor, Araneus sicki, Eustala sp10, Larinia t-notata and Metazigia gregalis were captured only in grassland areas, while Alpaida sp2, Wagneriana sp1, Parawixia audax and Miagrammopes sp1 were captured only in the swamp. Eustala sp1 was the most captured species in the Araucaria forest $(n=163)$ and in the swamp $(n=8)$, while Araneus corporosus was the most collected species in the grassland areas $(\mathrm{n}=77)$ (Table 1$)$.

\subsection{Habitat similarity}

Grassland and swamp areas were more similar each other than to the Araucaria Forest, according to presenceabsence of spider species in T. lactitarse's diet and species abundance in these habitats (Figures 3 e 4).

The diversity of spider species used by T. lactitarse was significantly higher in the swamp than in the Araucaria forest $(\mathrm{t}=4.975 ; \mathrm{P}<0.001)$ and in the grassland areas $(t=6.858 ; P<0.001)$, but there was no significant difference between the Araucaria forest and the grassland area $(\mathrm{t}=0.693 ; 0.5>\mathrm{P}>0.2)$. The Araucaria forest presented the highest spider species richness, followed by swamp areas and grasslands. Equitability was highest in swamp areas, followed by grasslands and Araucaria forest (Table 2).

Figure 5 shows that, not taking into account the different habitats, spiders can be divided into 3 groups according to abundance. The smaller group includes the most abundant species (Eustala sp1, Eustala sp2, Acacesia villalobosi, Alpaida sp1 and Araneus corporosus), i.e., those most commonly captured by $T$. lactitarse. The second group includes species represented by a range of 17 to 39 individuals (Wagneriana iguape, Araneus omnicolor, Eustala sp4, Alpaida grayi, Eustala $\mathrm{sp3}$, Larinia t-notata,

Araucaria forest

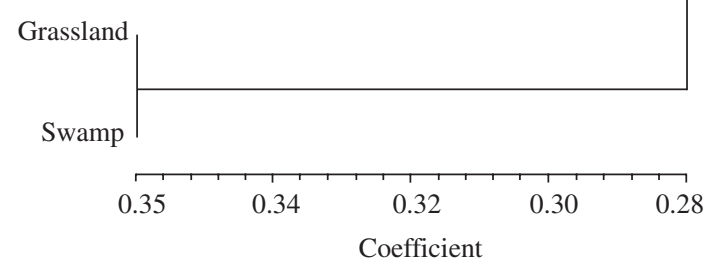

Figure 3. Dissimilarity dendrogram between the habitats related to their spider presence-absence in T. lactitarse diet.
Mangora sp1 and Wagneriana iguape). The third and largest group includes the less abundant species, represented by a range of 3 to 10 individuals (Aysha gr. brevimana 1 , Eustala sp5, Wagneriana eupalaestra, Alpaida scriba, Alpaida veniliae, Araneus aff. omnicolor, Araneus sicki, Eustala sp8, Mangora sp2, Mangora sp3, Wagneriana juquia, Alpaida sp2, Araneus blumenau, Eustala sp6, Eustala sp7 and Ocrepeira galianoae). Twenty five species were not included in the analysis because they were represented by only 1 or 2 individuals, preventing the interpretation of the resulting dendrograms. A similar pattern emerged from the dominance indices, with a group of dominant species and a group of accidental species. The differences between both analyses were observed in the group of accessory (or intermediate) species that was smaller than the group of intermediate species shown by the dendrogram (Table 3 ).

\subsection{Seasonality of juveniles, males and females}

A total of 1,132 juvenile spiders (56\%), 765 females (38\%) and 132 males (6\%) were captured by T. lactitarse. These percentages are significantly different between them (Table 4).

Juveniles were present throughout the 10 month sampling period, but were most frequent in January (21\%), March (20\%) and April (19\%). Females were captured during 9 months, being most frequent in January (27\%), February (16\%) and December (20\%). Males were captured during 8 months and were most frequent in January (26\%), March (25\%) and December (17\%) (Figure 6).

\section{Discussion}

The results of this study corroborate those presented by Camillo and Brescovit (1999a) on spiders collected by $T$. lactitarse in southeastern Brazil. In both studies Araneidae was the most frequent spider family in the composition of $T$. lactitarse's diet. The preference of these spiders by Trypoxylon has also been observed by other authors in different regions of the country (Coville, 1981; 1982; Rehnberg, 1987; Garcia and Adis, 1995; Camillo and Brescovit, 1999b; 2000), and seems to be a pattern among species of the subgenus Trypargilum. Nevertheless, according to Genaro and Alayon (1994), even if this pattern exists, the proportion and composition of species indicates that prey selection does not follow

Araucaria forest

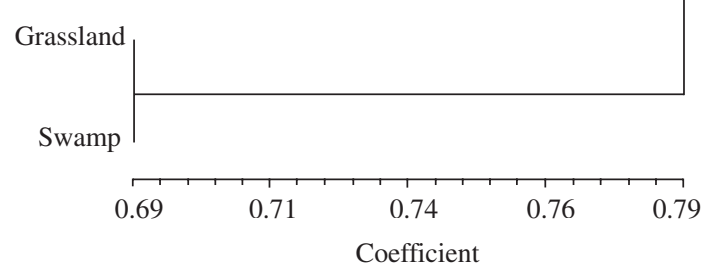

Figure 4. Dissimilarity dendrogram between the habitats related to their spider abundance in $T$. lactitarse diet. 
Table 1. Number of juvenile (J), male (M) and female (F) spiders collected by T. lactitarse in different habitats at the Parque Municipal das Araucárias.

\begin{tabular}{|c|c|c|c|c|c|c|c|c|c|}
\hline \multirow[t]{2}{*}{ Family/Species } & \multicolumn{3}{|c|}{$\begin{array}{c}\text { Araucaria } \\
\text { florest }\end{array}$} & \multicolumn{3}{|c|}{ Grassland } & \multicolumn{3}{|c|}{ Swamp } \\
\hline & $\mathbf{J}$ & $\mathbf{M}$ & $\mathbf{F}$ & $\mathbf{J}$ & $\mathbf{M}$ & $\mathbf{F}$ & $\mathbf{J}$ & M & $\mathbf{F}$ \\
\hline \multicolumn{10}{|l|}{ ANYPHAENIDAE } \\
\hline $\begin{array}{l}\text { Aysha aff. borgmeyeri } \\
\text { (Mello-Leitão) }\end{array}$ & - & - & 1 & - & - & 1 & - & - & - \\
\hline $\begin{array}{l}\text { Aysha gr. brevimana } 1 \\
\text { (C.L.Koch) }\end{array}$ & 1 & 2 & 1 & - & - & 1 & - & - & - \\
\hline $\begin{array}{l}\text { Aysha gr. brevimana } 4 \\
\text { (C.L.Koch) }\end{array}$ & - & - & 1 & - & - & - & - & - & - \\
\hline $\begin{array}{l}\text { Aysha rubromaculata } \\
\text { (Keyserling) }\end{array}$ & - & - & 1 & - & - & - & - & - & - \\
\hline Aysha sp3 & - & - & 1 & - & - & - & - & - & - \\
\hline Sanogasta sp3 & - & - & - & - & - & 1 & - & - & - \\
\hline \multicolumn{10}{|l|}{ ARANEIDAE } \\
\hline Acacesia villalobosi Glueck & 2 & 1 & 91 & - & 2 & 14 & - & - & 5 \\
\hline Alpaida gracia Levi & - & - & 1 & - & - & - & - & - & - \\
\hline Alpaida grayi (Blackwall) & 3 & 7 & 9 & - & - & 1 & - & - & - \\
\hline Alpaida scriba Levi & - & - & 2 & - & - & - & - & - & 1 \\
\hline Alpaida sp1 & 8 & 3 & 102 & - & - & - & - & 1 & 2 \\
\hline Alpaida sp2 & - & - & - & - & - & - & - & - & 4 \\
\hline Alpaida veniliae (Keyserling) & - & 2 & 1 & - & - & - & - & - & - \\
\hline $\begin{array}{l}\text { Araneus aff. omnicolor } \\
\text { Keyserling }\end{array}$ & & 2 & 1 & - & - & - & - & - & - \\
\hline $\begin{array}{l}\text { Araneus aurantiifemuris } \\
\text { (Mello-Leitão) }\end{array}$ & - & - & 1 & - & - & - & - & - & - \\
\hline Araneus blumenau Levi & - & - & - & - & 3 & 4 & - & 1 & - \\
\hline $\begin{array}{l}\text { Araneus corporosus } \\
\text { (Keyserling) }\end{array}$ & 3 & 3 & 3 & 1 & 12 & 64 & - & - & 1 \\
\hline $\begin{array}{l}\text { Araneus omnicolor } \\
\text { (Keyserling) }\end{array}$ & - & 2 & 3 & - & 3 & 8 & - & - & 4 \\
\hline Araneus sicki Levi & - & - & - & - & - & 3 & - & - & - \\
\hline Bertrana rufostriata Simon & - & - & 2 & - & - & - & - & - & - \\
\hline Eustala $\mathrm{sp} 1$ & 2 & 24 & 137 & 5 & 7 & 13 & - & - & 8 \\
\hline Eustala sp2 & 10 & 19 & 98 & 2 & 4 & 18 & & 1 & 4 \\
\hline Eustala sp3 & - & 4 & 20 & - & 1 & 3 & - & - & - \\
\hline Eustala sp4 & - & - & - & - & 1 & 13 & - & - & 6 \\
\hline Eustala sp5 & - & 1 & 4 & - & - & - & - & - & - \\
\hline Eustala sp6 & - & - & 3 & - & - & 4 & - & - & - \\
\hline Eustala sp7 & - & - & 2 & - & - & 3 & - & - & 2 \\
\hline Eustala sp8 & - & - & - & - & - & 2 & - & - & 1 \\
\hline Eustala sp9 & - & - & 1 & - & - & - & - & - & 1 \\
\hline Eustala sp10 & - & - & - & - & - & 1 & - & - & - \\
\hline Larinia t-notata (Tullgren) & - & - & - & - & 11 & 28 & - & - & - \\
\hline Mangora sp1 & 5 & 7 & 10 & - & - & 1 & - & - & 1 \\
\hline Mangora sp2 & - & 1 & 2 & - & - & - & - & - & - \\
\hline Mangora sp3 & - & - & 2 & - & - & 1 & - & - & - \\
\hline Mangora sp5 & - & - & 1 & - & - & - & - & - & - \\
\hline
\end{tabular}


Table 1. Continued...

\begin{tabular}{|c|c|c|c|c|c|c|c|c|c|}
\hline \multirow[t]{2}{*}{ Family/Species } & \multicolumn{3}{|c|}{$\begin{array}{c}\text { Araucaria } \\
\text { florest }\end{array}$} & \multicolumn{3}{|c|}{ Grassland } & \multicolumn{3}{|c|}{ Swamp } \\
\hline & $\mathbf{J}$ & $\mathbf{M}$ & $\mathbf{F}$ & $\mathbf{J}$ & M & $\mathbf{F}$ & $\mathbf{J}$ & $\mathbf{M}$ & $\mathbf{F}$ \\
\hline $\begin{array}{l}\text { Metazygia gregalis } \\
\text { O. P.-Cambridge }\end{array}$ & - & - & - & - & 1 & - & - & - & - \\
\hline Ocrepeira galianoae Levi & - & 3 & 5 & - & 1 & 1 & - & - & - \\
\hline Parawixia audax (Blackwall) & - & - & - & - & - & - & - & 1 & - \\
\hline $\begin{array}{l}\text { Wagneriana eupalaestra } \\
\text { (Mello-Leitão) }\end{array}$ & - & - & 5 & - & - & - & - & - & - \\
\hline Wagneriana iguape Levi & - & 1 & 12 & - & - & - & - & - & 4 \\
\hline Wagneriana janeiro Levi & - & - & 1 & - & - & - & - & - & - \\
\hline Wagneriana juquia Levi & - & - & 2 & - & - & - & - & - & 1 \\
\hline $\begin{array}{l}\text { Wagneriana neglecta } \\
\text { (Mello-Leitão) }\end{array}$ & - & - & 1 & - & - & - & - & - & - \\
\hline Wagneriana sp1 & - & - & - & - & - & - & - & - & 1 \\
\hline \multicolumn{10}{|l|}{ DEINOPIDAE } \\
\hline Deinops sp1 & 1 & - & - & - & - & - & - & - & - \\
\hline OXYOPIDAE & 1 & & & & & & & & \\
\hline \multicolumn{10}{|l|}{ SALTICIDAE } \\
\hline gen. sp2 (indeterminate) & 1 & - & - & - & - & - & - & - & - \\
\hline \multicolumn{10}{|l|}{ TETRAGNATHIDAE } \\
\hline Chrysometa boraceia Levi & - & - & 1 & - & - & - & - & - & - \\
\hline $\begin{array}{l}\text { Chrysometa ludibunda } \\
\text { (Keyserling) }\end{array}$ & - & - & 1 & - & - & - & - & - & - \\
\hline Chrysometa sp2 & - & - & 2 & - & - & - & - & - & - \\
\hline Leucauge sp. & - & - & 1 & - & - & - & - & - & - \\
\hline Tetragnatha sp1 & - & - & 1 & - & - & - & - & - & - \\
\hline \multicolumn{10}{|l|}{ ULOBORIDAE } \\
\hline Miagrammopes sp1 & - & - & - & - & - & - & - & - & 1 \\
\hline
\end{tabular}

an automatic and inflexible behavior pattern, but rather an adaptive response to their abundance and distribution. This is observed when we compare the results of the present study with those presented by Camillo and Brescovit (1999a). A total of 56 species of spiders were collected by $T$. lactitarse in the study carried out by Brescovit and Camillo and 53 were collected in the present study. Even though Eustala was the most frequently collected genera, only four species were common to all studies. Other papers dealing with T. lactitarse (Camillo et al., 1993; Camillo and Brescovit, 1999b) and species of Trypoxylon (Coville, 1979; 1982; Brockmann and Grafen, 1992; Camillo et al., 1994; Camillo and Brescovit, 1999b; Coville et al., 2000), showed that, although Araneidae species were also the most frequently collected, Alpaida, Neoscona, Metazygia, Metepeira, Araneus and Acacesia were the most frequently collected genera.

In a study concerned with prey preference of Trypargilum wasps, carried out by Coville (1982), all species take substantial percentages of orb weaving
Araneidae. The albitarse group was virtually restricted to Araneidae, most commonly the genera Eustala, Neoscona, and, less frequently, Araneus. For species in the nitidium group, prey preferences vary from snare building spiders, primarily Araneidae, and Theridiidae. Members in the spinosum complex normally take a wide variety of snare building and wandering spiders found in vegetation and manmade structures. The punctulatum complex also strongly favors snare builders, primarily Araneidae, but in a large sample of $T$. lactitarse diet a wide variety of spider families are represented by small percentages.

Snare builder spiders normally build webs that entangle their prey and wanderers pursue or ambush their prey. A preference for snare building spiders by $T$. lactitarse does not necessarily mean that wasps hunt for spiders that are on webs (Coville et al., 2000). Griswold and Coville (1986) noted that diurnal habits of prey of Trypoxylon vagulum Richards at La Selva fall into 5 patterns, all but the last pertain to snare building species (on intact web; at the edge of intact webs; cryptic 


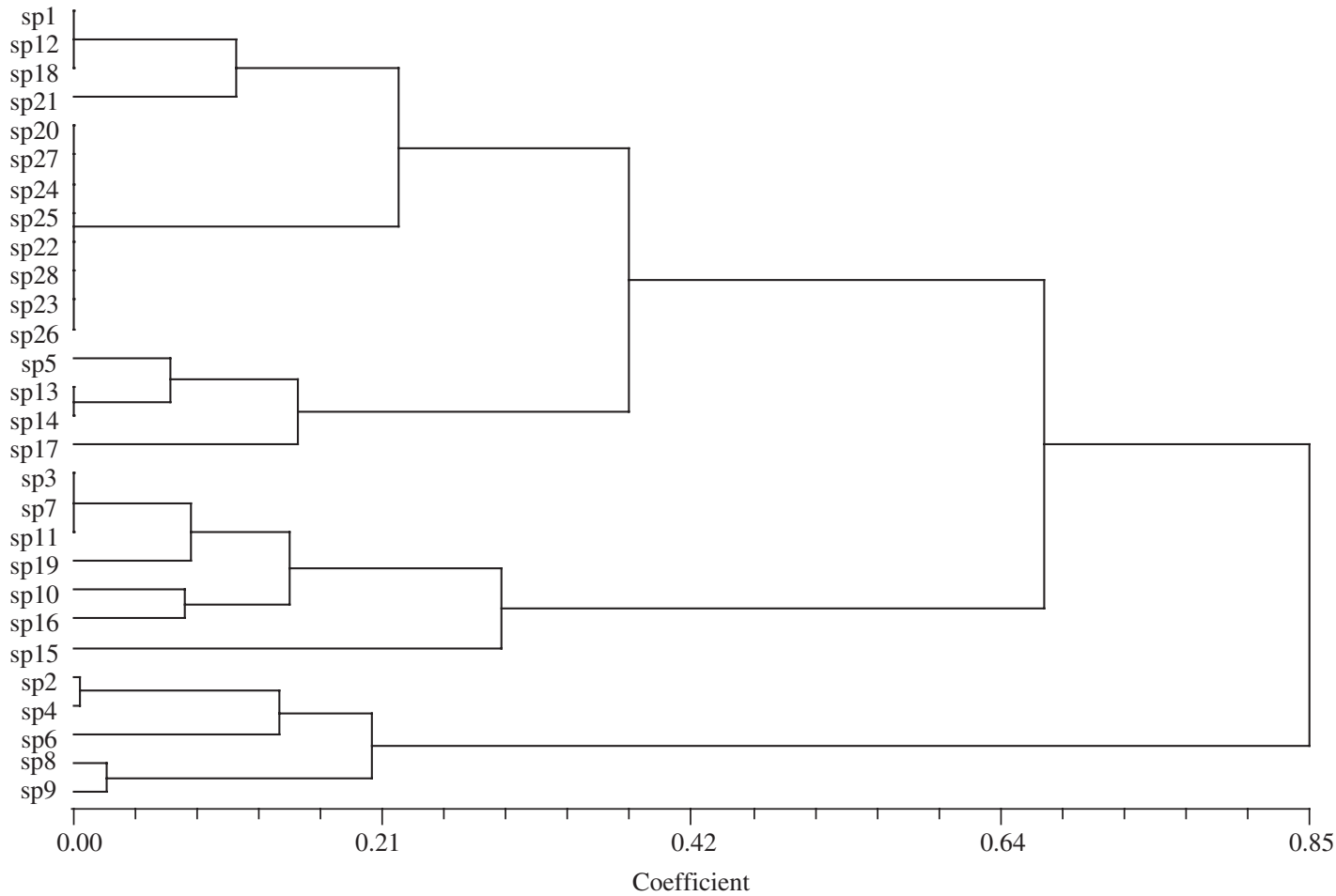

Figure 5. Dissimilarity dendrogram between spiders species related to their abundances in $T$. lactitarse diet: Sp1= Aysha gr. breviana $1 ; \mathrm{Sp} 2=$ Acacesia villalobosi $; \mathrm{Sp} 3=$ Alpaida grayi $; \mathrm{Sp} 4=$ Alpaida $\mathrm{sp} 1 ; \mathrm{Sp} 5=$ Araneus blumenau $; \mathrm{Sp} 6=$ Araneus corporosus; $\mathrm{Sp} 7=$ Araneus omnicolor; $\mathrm{Sp} 8=$ Eustala $\mathrm{sp} 1 ; \mathrm{Sp} 9=$ Eustala $\mathrm{sp} 2 ; \mathrm{Sp} 10=$ Eustala $\mathrm{sp} 3 ; \mathrm{Sp} 11=$ Eustala sp4; Sp12 = Eustala sp5; Sp13 = Eustala sp6; Sp14 = Eustala sp7; Sp15 = Larinia t-notata $;$ Sp16 = Mangora sp1; Sp17 = Ocrepeira galianae $;$ Sp18 = Wagneriana eupalaestra $;$ Sp19 = Wagneriana iguape $;$ Sp20 = Eustala $\mathrm{sp} 8 ;$ Sp21 = Alpaida $\mathrm{sp} 2 ; \mathrm{Sp} 22=$ Mangora $\mathrm{sp} 2 ; \mathrm{Sp} 23=$ Mangora $\mathrm{sp} 3 ; \mathrm{Sp} 24=$ Alpaida scriba $; \mathrm{Sp} 25=$ Alpaida veniliae $; \mathrm{Sp} 26=$ Araneus aff. omnicolor $; \mathrm{Sp} 27=$ Araneus sicki; $\mathrm{Sp28}=$ Wagneriana juquia .

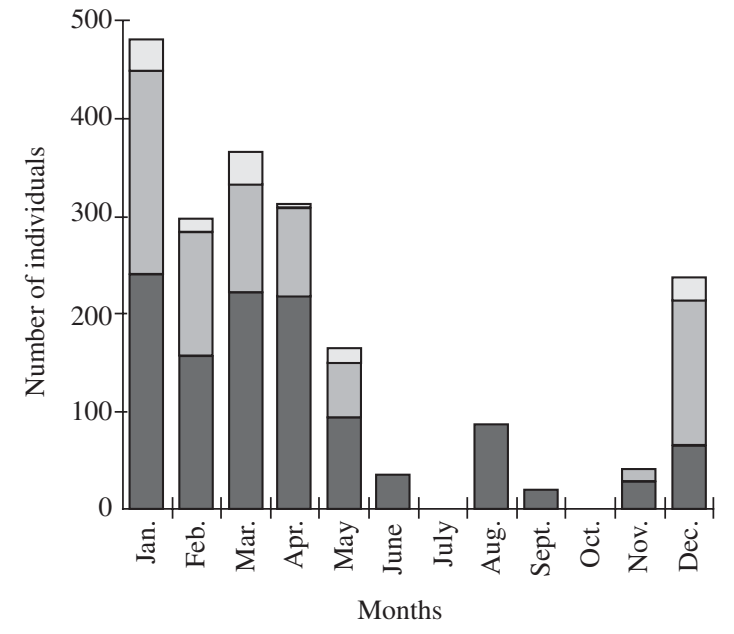

$\square$ Juveniles $\square$ Females $\square$ Males

Figure 6. Monthly percent of juveniles, males and females of the spiders prey hunted by $T$. lactitarse at the Parque Municipal das Araucárias from December 2001 to December 2004.
Table 2. Abundance (A), richness $\left(\mathrm{D}_{\mathrm{g}}\right)$, diversity $\left(\mathrm{H}^{*}\right)$ and eveness (J') index of spiders in $T$. lactitarse diet in three habitats.

\begin{tabular}{lrrrc}
\hline \multicolumn{1}{c}{ Habitat } & \multicolumn{1}{c}{ A } & H' & D $_{\mathbf{M g}}$ & J' \\
\hline Araucaria forest & 652 & 0.996 & 14.214 & 0.617 \\
Swamp & 51 & 1.156 & 10.541 & 0.904 \\
Grassland & 232 & 0.968 & 8.830 & 0.721 \\
\hline
\end{tabular}

on substrate, no retreat, intact web present; cryptic on substrate, retreat and web absent; motionless, exposed on foliage).

Camillo and Brescovit (1999a; 2000) considered H' the reproductive niche widths and, according to these authors, $\mathrm{H}^{\prime}$ were smaller in T. rogenhoferi $\mathrm{Kohl}\left(\mathrm{H}^{\prime}=1.25\right.$; $\left.H^{\prime}=1.30 ; H^{\prime}=1.29\right)$ than $T$. lactitarse $\left(H^{\prime}=2.24\right.$; $H^{\prime}=2.72$ and $\left.H^{\prime}=1.79\right)$ in three different habitats. Comparing our values $\left(\mathrm{H}^{\prime}=0.97 ; \mathrm{H}^{\prime}=1.00 ; \mathrm{H}^{\prime}=1.16\right)$ to those obtained by Camillo and Brescovit (1999a; 2000) we note that in Guarapuava, T. lactitarse presented a lower niche amplitude. This could be related to the lower 
Table 3. List of spider species and their respective dominance indices.

\begin{tabular}{|c|c|c|}
\hline Family/Species & $\begin{array}{l}\text { Dominance } \\
\text { index (D) }\end{array}$ & $\begin{array}{l}\text { Dominance } \\
\text { classification }\end{array}$ \\
\hline \multicolumn{3}{|l|}{ ANYPHAENIDAE } \\
\hline Aysha aff. borgmeyeri & 0.21 & accidental \\
\hline Aysha gr. brevimana 1 & 0.53 & accidental \\
\hline Aysha gr. brevimana 4 & 0.11 & accidental \\
\hline Aysha rubromaculata & 0.11 & accidental \\
\hline Aysha sp3 & 0.11 & accidental \\
\hline Sanogasta sp3 & 0.11 & accidental \\
\hline \multicolumn{3}{|l|}{ ARANEIDAE } \\
\hline Acacesia villalobosi & 12.2 & dominant \\
\hline Alpaida gracia & 0.11 & accidental \\
\hline Alpaida grayi & 2.1 & accidental \\
\hline Alpaida scriba & 0.32 & accidental \\
\hline Alpaida sp1 & 12.3 & dominant \\
\hline Alpaida sp2 & 0.42 & accidental \\
\hline Alpaida veniliae & 0.32 & accidental \\
\hline Araneus aff. omnicolor & 0.32 & accidental \\
\hline Araneus aurantiifemuris & 0.11 & accidental \\
\hline Araneus blumenau & 0.85 & accidental \\
\hline Araneus corporosus & 9.20 & dominant \\
\hline Araneus omnicolor & 2.12 & accidental \\
\hline Araneus sicki & 0.32 & accidental \\
\hline Bertrana rufostriata & 0.21 & accidental \\
\hline Eustala sp1 & 20.8 & dominant \\
\hline Eustala sp2 & 16.6 & dominant \\
\hline Eustala sp3 & 3.00 & accessory \\
\hline Eustala sp4 & 2.12 & accidental \\
\hline Eustala sp5 & 0.53 & accidental \\
\hline Eustala sp6 & 0.74 & accidental \\
\hline Eustala sp7 & 0.74 & accidental \\
\hline Eustala sp8 & 0.32 & accidental \\
\hline Eustala sp9 & 0.21 & accidental \\
\hline Eustala sp10 & 0.11 & accidental \\
\hline Larinia t-notata & 4.10 & accessory \\
\hline Mangora sp1 & 2.50 & accessory \\
\hline Mangora sp2 & 0.32 & accidental \\
\hline Mangora sp3 & 0.11 & accidental \\
\hline Mangora sp5 & 0.32 & accidental \\
\hline Metazygia gregalis & 0.11 & accidental \\
\hline Ocrepeira galianoae & 1.10 & accidental \\
\hline Parawixia audax & 0.11 & accidental \\
\hline Wagneriana eupalaestra & 0.53 & accidental \\
\hline Wagneriana iguape & 1.81 & accidental \\
\hline Wagneriana janeiro & 0.11 & accidental \\
\hline Wagneriana juquia & 0.32 & accidental \\
\hline Wagneriana neglecta & 0.11 & accidental \\
\hline Wagneriana sp1 & 0.11 & accidental \\
\hline \multicolumn{3}{|l|}{ DEINOPIDAE } \\
\hline Deinops sp1 & 0.11 & accidental \\
\hline OXYOPIDAE & 0.11 & accidental \\
\hline \multicolumn{3}{|l|}{ SALTICIDAE } \\
\hline gen. sp2 (indeterminate) & 0.11 & accidental \\
\hline \multicolumn{3}{|l|}{ TETRAGNATHIDAE } \\
\hline Chrysometa boraceia & 0.11 & accidental \\
\hline Chrysometa ludibunda & 0.11 & accidental \\
\hline Chrysometa sp2 & 0.21 & accidental \\
\hline Leucauge sp & 0.11 & accidental \\
\hline Tetragnatha $\mathrm{sp} 1$ & 0.11 & accidental \\
\hline \multicolumn{3}{|l|}{ ULOBORIDAE } \\
\hline Miagrammopes sp1 & 0.11 & accidental \\
\hline
\end{tabular}

Table 4. Qui-square test between the percentages of juveniles, females and males used by T. lactitarse in its diet.

\begin{tabular}{lcc}
\hline \multicolumn{1}{c}{ Comparisons } & $\begin{array}{c}\text { Qui-square } \\
\text { values }\end{array}$ & Probabilities \\
\hline Juveniles x Females & 16.412 & $\mathrm{P}<0.01$ \\
Juveniles x Males & 52.705 & $\mathrm{P}<0.01$ \\
Females x Males & 36.292 & $\mathrm{P}<0.01$ \\
\hline
\end{tabular}

spider diversity in subtropical regions. We also evidence that $T$. lactitarse is a generalist species and thus is more flexible towards regional prey availability, enhancing its adaptive capacity. Rehnberg (1987) states that the adaptive capacity of wasps of this guild varies not only from region to region, but also throughout the seasons in the same region. According to the author, alterations in the spider species composition of the diet of some species of insects could occur because the size of the spiders varies throughout the year, and thus the energetic value also varies. In the diet of T. politum Say, species of the genus Eustala were more frequent in spring and the beginning of summer, when they are clearly larger than several specimens of Neoscona and Araneus collected at the same time. In other periods they are relatively small and, according to this author, not energetically attractive. If the energy obtained from small spiders is very low, a shift to a large species could be adaptive. Although Guarapuava is a subtropical region and considered the second coldest city in Paraná, we did not observe a species substitution in the diet of $T$. lactitarse throughout the year.

According to Brockmann and Grafen (1992) the size of the spider can negatively affect the composition of $T$. politum's diet, because as they grow they become more difficult to transport. In northern Florida, through most of the season, this wasp hunts Neoscona spiders (98\% of prey items), and most of these belong to a single species, $N$. domiciliorum Hentz. According to these authors, this species overwinters as spiderlings, so as the season progresses, their size increases and they become more difficult to transport to the nest.

Another factor that seems to affect the composition of spider species is the fact that when they reach the adult stage they become more dangerous to hunt, since adult spiders can catch wasps, as is the case of Neoscona (Brockmann and Grafen, 1992). Thus, the wasp can start using another species that is still in the juvenile stages. This is probably one of the reasons why juveniles are always present in large quantities in the diet of the majority of the studied species of wasps (Coville, 1981; 1982; Coville and Coville, 1980; Brockmann and Grafen, 1992; Genaro and Alayon, 1994; Camillo and Brescovit, 1999a, b; 2000), even though Rehnberg (1987) did also observe a variation in the quantities of juveniles throughout the year. According to this author, although relative availabilities of life stages are unknown, the decline probably reflected the mortality of juveniles or growth into 
sub adults. Camillo and Brescovit (1999a) state that a higher proportion of juveniles throughout the year probably indicates the occurrence of more than one generation per year in some of the sample prey species, which must also be related to the fact that $T$. lactitarse has at least four generations per year in southeastern Brazil. In our region, T. lactitarse also presented up to four generations per year (Buschini, 2007) and the proportion of juveniles was always higher than that of adults.

In the studies that are being carried out on prey used by this wasp guild, the proportion of males in the diets has always been lower than that of females and juveniles (Coville, 1981; 1982; Coville and Coville, 1980; Rehngerg, 1987; Brockmann and Grafen, 1992; Genaro and Alayon, 1994; Camillo and Brescovit, 1999a, b; 2000). The relative absence of adult male spiders in provisions might be a result of behavior patterns found in Araneidae, since they are substantially smaller than adult females (Berman and Levi, 1971; Levi, 1971) and spin a correspondingly smaller, less visible web (Waldorf, 1976). As sexual maturity is reached, female araneids continue to occupy webs and feed; males cease feeding and search for females (Gertsch cited by Rehnberg, 1987).

Acknowledgements - Partial financial support was provided by the Fundação Araucária (The State of Paraná Research Foundation, CNPq and UNICENTRO (Guarapuava - PR, Brazil). I thank Prof. Msc. Sérgio Bazílio from UNICENTRO (PR, Brazil) for some help.

\section{References}

BERMAN, JD. and LEVI, HW., 1971. The orb weaver genus Neoscona in North America (Araneae: Araneidae). Bull Mus. Comp. Zool. vol. 141, no. 8, p. 465-500.

BOHART, RM. and MENKE, AS., 1976. Sphecidae wasps of the world. Berkeley: University of California.

BROCKMANN, HJ. and GRAFEN, A., 1989. Male conflict and male behavior in a solitary wasp, Trypoxylon (Trypargilum) politum (Hymenoptera: Sphecidae). Anim. Behav., vol. 37, no. 2, p. 232-255.

BROCKMANN, HJ. and GRAFEN, A., 1992. Sex ratios and life-history patterns of solitary wasp, Trypoxylon (Trypargilum) politum (Hymenoptera: Sphecidae). Behav. Ecol. Sociobiol., vol. 30 , no. 1 , p. 7-27.

BUSCHINI, MLT. 2007. Life-history and sex allocation in Trypoxylon (syn. Trypargilum) lactitarse (Hymenoptera; Crabronidae). J. Zool. Syst. Evol. Res. vol. 45, p. 206-213.

BUSCHINI, MLT. and WOLFF, LL., 2006. Nesting biology of Trypoxylon (Trypargilum) lactitarse Saussure (Hymenoptera, Crabronidae) in trap-nests in southern Brazil. Rev. Bras. Biol. = Braz. J. Biol. vol. 66, no. 3, p. 919-929.

CAMILlO, E. and BRESCOVIT, AD., 1999a. Spiders (Ananeae) captured by Trypoxylon (Trypargilum) lactitarse (Hymenoptera: in southeastern Brazil). Rev. Biol. Trop., vol. 47, no. $1-2$, p. $151-162$.
-, 1999b. Aspectos biológicos de Trypoxylon (Trypargilum) lactitarse Saussure e Trypoxylon (Trypargilum) rogenhoferi Kohl (Hymenoptera: Sphecidae) em ninhos-armadilhas, com especial referência as suas presas. An. Soc. Entomol. Brasil, vol. 28 , no. 2 , p. 251-261.

-, 2000. Spider prey (Araneae) of Trypoxylon (Trypargilum) rogenhoferi (Hymenoptera: Sphecidae) in southeastern Brazil. Rev. Biol. Trop., vol. 48, no. 2-3, p. 647-656.

CAMIllo, EC., GARÓFAlO, CA., MUCCILIO, G. and SERRANO, JC., 1993. Biological observation on Trypoxylon (Trypargilum) lactitarse Saussure in Southeastern Brazil (Hymenoptera, Sphecidae). Rev. Bras. Entomol., vol. 37, no. 4, p. 769-778.

CAMILlO, E., GAROFALO, CA. and SERRANO, JC., 1994. Observações sobre a biologia de Trypoxylon (Trypargilum) rogenhoferi Kohl (Hymenoptera: Sphecidae). An. Soc. Entomol. Brasil, vol. 23, no. 2, p. 299-309.

COVILLE, RE., 1979. Biological observations on Trypoxylon (Tripargilum) arizonense in Arizona (Hymenoptera: Sphecidae). J. Kansas Entomol., vol. 52, no. 3, p. 613-620.

-, 1981. Biological observations on three Trypoxylon wasps in the subgenus Tripargilum from Costa Rica: T. nitidiu schultesi, T. saussurei and T. lactitarse (Hymenoptera: sphecidae). Pan-Pacif. Ent., vol. 57, no. 2, p. 332-340.

-, 1982. Wasps of the genus Trypoxylon sub genus Tripargilum in the North America. Berkeley: University of California.

-, 1987. Spider-hunting sphecid wasps. In Nentwig, W. (Ed.). Ecophysiolosy of spiders. Berlin: Springer. p. 309-318.

COVILLE, RE., and COVILLE, PL., 1980. Nesting biology and male behavior of Trypoxylon (Trypargilum) tenoctitlan in Costa Rica (Hymenoptera: Sphecidae). Ann. Entomol. Soc. Am., vol. 73, no. 1, p. 110-119.

COVILLE, RE., GRISWOLD, CE. and COVILLE, PL., 2000. Observations on the nesting biology and behavior of Trypoxylon (Trypargilum) vagumm (Hymenoptera: Sphecidae) in Costa Rica. Pan-Pacif. Ent., vol. 76, no. 1, p. 28-48.

GARCIA, MVB. and ADIS, J., 1995. Comportamento de nidificação de Trypoxylon (Trypargilum) rogenhoferi Kohl (Hymenoptera, Sphecidae) em uma floresta inundável de várzea na Amazônia Central. Amazoniana, vol. 13, no. 3-4, p. 259-282.

GENARO, JA., SANCHEZ, CS. and ALAYÓN, G., 1989. Notas sobre la conducta de nidificación de Trypoxylon (Trypargilum) subimpressum Smith (Hymenoptera, Sphecidae). Caribbean J. Sci., vol. 25, no. 1, p. 228-229.

GENARO, JA. and ALAYÓN, G., 1994. Las presas (Araneae) de Trypoxylon (Trypargilum) subimpressum (Hymenoptera: Sphecidae) em Cuba. Rev. Biol. Trop., vol. 42, no. 1-2, p. 353-356.

GRISWOLD, CE. and COVILLE, RE., 1986. Observations on the prey and nesting biology of spider-hunting wasps of the genus Trypoxylon (Hymenoptera: Sphecidae) in Costa Rica. In Proceedings of the 9 International Congress of Arachnology (Panama 1983). Republic of Panama, Balboa, Smithsonian Tropical Research Institute, p. 113-116.

KROMBEIN, KV., 1967. Trap-nesting wasps and bees. Life histories, and associates. Washington: Smithsonian Institution. 
LEVI, HW., 1971. The diadematus group of the orb-weaver genus Araneus north of Mexico (Araneae: Araneidae). Bull. Mus. Comp. Zool., vol. 141, no. 4, p. 131-179.

LUDWIG, JA. and REYNOLDS, JF., 1988. Statistical ecology: a primer on methods and computing. New York: John Wiley and Sons.

MANTEL, N., 1967. The detection of disease clustering and a generalized regression approach. Cancer Research, vol. 27, no. 1 , p. 133-153.

MATTHEWS, RW. and MATTHEWS, JR., 1968. A note on Trypoxylon arizonense in trap nests from Arizona, with a review of prey preferences and cocoon structure in the genus (Hymenoptera: Sphecidae). Psyche., vol. 75, no. 3, p. 285-293.
PALMA, S., 1975. Contribución al estudio de los sifonoforos encontrados frente a la costa de Valparaiso. Aspectos ecológicos. In 2 Simpósio Latino Americano sobre Oceanografia Biológica. Venezuela: Univ. D’Oriente, p. 119-133.

REHNBERG, BG., 1987. Selection of spiders prey by Trypoxylon politum (Say) (Hymenoptera: Sphecidae). Can. Ent., vol. 119, no. 2, p. 189-194.

RICHARDS, OW., 1934. The americam species of the genus Trypoxylon. R. Entomol. Soc. Lond. vol. 82, no. 1, p. 173-362.

WALDORF, ES., 1976. Spider size, microhabitat selection, and use of food. Am. Midl. Nat., vol. 96, no. 1, p. 76-87. 